\title{
Toxicity of cadmium and zinc on two microalgae, Scenedesmus obliquus and Desmodesmus pleiomorphus, from Northern Portugal
}

\author{
Cristina M. Monteiro • Susana C. Fonseca • \\ Paula M. L. Castro $\cdot$ F. Xavier Malcata
}

\begin{abstract}
Aquatic environments often contain toxic heavy metals that may enter the food web via uptake by microalgae and eventually cause severe poisoning problems at higher trophic levels. The effects of $\mathrm{Cd}$ and $\mathrm{Zn}$ cations upon growth of two native green microalgal species, Scenedesmus obliquus and Desmodesmus pleiomorphus (previously isolated from a polluted site in Northern Portugal), were accordingly evaluated. Growth inhibition of the microalgal cells was determined following exposure for $96 \mathrm{~h}$ to several initial concentrations of aqueous solutions of either of those two metals. At the higher end of $\mathrm{Cd}$ and $\mathrm{Zn}$ experimental concentration ranges, a significant reduction in cell density was observed in the cultures; $\mathrm{EC}_{50}$ values, calculated after fitting a Weibull model to the experimental data, were 0.058
\end{abstract}

C. M. Monteiro · S. C. Fonseca • P. M. L. Castro

$\mathrm{CBQF} /$ Escola Superior de Biotecnologia,

Universidade Católica Portuguesa,

Rua Dr. António Bernardino de Almeida,

4200-072 Porto, Portugal

S. C. Fonseca

School of Technology and Management,

Viana do Castelo Polytechnic Institute,

Avenida do Atlântico,

4900-348 Viana do Castelo, Portugal

F. X. Malcata $(\bowtie)$

Avenida Carlos Oliveira Campos,

ISMAI-Instituto Superior da Maia,

Castelo da Maia,

4475-690 Avioso S. Pedro, Portugal

e-mail: fmalcata@ismai.pt

F. X. Malcata

CIMAR/CIIMAR-Centro Interdisciplinar de Investigação

Marinha e Ambiental,

Rua dos Bragas no. 289,

4050-123 Porto, Portugal and $1.92 \mathrm{mg} \mathrm{L}^{-1}$ for $\mathrm{Cd}$ and 16.99 and $4.87 \mathrm{mg} \mathrm{L}^{-1}$ for $\mathrm{Zn}$ in the case of $S$. obliquus and D. pleiomorphus, respectively. One observed that $S$. obliquus can tolerate higher $\mathrm{Zn}$ concentrations than D. pleiomorphus, but the reverse holds regarding exposure to $\mathrm{Cd}$.

Keywords Microalgae $\cdot$ Heavy metals $\cdot \mathrm{Cd} \cdot \mathrm{Zn} \cdot \mathrm{EC}_{50}$. Weibull model

\section{Introduction}

Aquatic ecosystems have become increasingly contaminated by heavy metals as a consequence of release of wastewaters containing such pollutants generated by anthropogenic sources; this poses a serious threat to human beings owing to their toxicity (even at minute concentrations), bioaccumulation and biomagnification in the food web (Herpin et al. 1996; Mohammed and Markert 2006; la Rocca et al. 2009). In fact, cadmium induces a wide spectrum of toxic effects upon plant physiology: it alters enzymatic activities via binding to functional groups or by displacing the metal therein (Báscik-Remisiewicz et al. 2009; Sanitá di Toppi and Gabbrielli 1999). On the other hand, zinc is an essential micronutrient for several organisms including microalgae and acts as an important enzyme cofactor (e.g. in carbonic anhydrase, superoxide dismutase and RNA polymerase); however, it becomes toxic when available in higher concentrations (viz., 100$500 \mathrm{mg} \mathrm{day}{ }^{-1}$; Báscik-Remisiewicz et al. 2009; Omar 2002a) since it decreases cell division, mobility, total chlorophyll content, ATPase activity and carotenoid/ chlorophyll ratio in microalgae (Omar 2002b).

Among the organisms more frequently used in vitro for toxicity tests, freshwater microalgae (Moreno-Garrido et al. 
2000) are particularly sensitive in detecting the potential toxic effects of pollutants (la Rocca et al. 2009); moreover, results of microalgal toxicity tests are relatively reliable and repeatable; finally, microalgae are ubiquitous in aquatic environments, and toxicity tests resorting to these organisms are relatively quick and inexpensive (Lam et al. 1999; Torres et al. 2000). Green algae and diatoms are the microalgae most commonly used for toxicity tests (MorenoGarrido et al. 2000), which, in their most standard form, measure the decrease in growth rate or in final cell biomass brought about by exposure to the appropriate metal for 48 up to $96 \mathrm{~h}$; growth endpoints are particularly relevant because changes in population growth may influence species succession, as well as community structure and function (Franklin et al. 2002).

The sensitivity of a toxicity test depends on the initial cell density (Franklin et al. 2002; Moreno-Garrido et al. 2000), and there is evidence indicating decreases in sensitivity upon increases in cellular levels (MorenoGarrido et al. 2000). Since the surface of microalgal cells is negatively charged, it provides a set of binding sites for metal cations (e.g. $\mathrm{Zn}^{2+}$ and $\mathrm{Cd}^{2+}$ ); hence, higher initial cell densities entail more surface ligands available and thus less ions per cell basis, which will likely lead to a lower toxic effect by the metal(s) onto the microalgal cells. For most protocols, the recommended initial cell density lies within $10^{3}-10^{5}$ cells $\mathrm{mL}^{-1}$ (OECD 2006; Wong and Couture 1986), yet Blaise and Ménard (1998) recommended a microalgal inoculum of $10^{6}$ cells $\mathrm{mL}^{-1}$.

Besides useful as the basis for assay methods, assessment of the toxicity of heavy metals in soluble form upon wild microalgae from contaminated sites is of particular relevance in ecotoxicology studies - especially because such wild strains are normally exposed to highly polluted environments, and are consequently more prone to conveying admission of metals into the food web. Although metal toxicity to microalga cells has sometimes been claimed to depend on the speciation of the metal, only divalent cationic forms are usually assumed by either $\mathrm{Zn}$ or $\mathrm{Cd}$. In addition, experimental evidence indicates that toxicity depends more strongly on the activity of the free metal ion rather than the total metal concentration: for example, Knauer et al. (1997) and Mbabazi et al. (2010) claimed that $\mathrm{Zn}$ and $\mathrm{Cd}$ were predominantly present in their cationic form, otherwise no toxicity was observed, whereas Allen et al. (1980) referred that the main forms of zinc in solution are $\mathrm{Zn}^{2+}$ and $\mathrm{ZnOH}^{+}$, both of which can be considered as free zinc divalent cations.

Toxicity studies encompassing microalgal species have for long been produced owing to their importance as crucial components at the basis of the food chain. However, only a minor fraction of those studies consid- ered microalgae isolated from polluted locations, yet such unique sources entail a potentially high resistance to toxic pollutants. Hence, a major significance of the ecotoxicity tests described in this paper derives from consideration of wild microalga strains that had systematically been exposed to severely stressing conditions of heavy metal contamination.

In this study, the effects of $\mathrm{Cd}$ and $\mathrm{Zn}$ cations upon the growth of two green microalga species, Scenedesmus obliquus and Desmodesmus pleiomorphus, which had previously been isolated from a polluted zone in Northern Portugal, were thus studied. To this deed, 96-h $\mathrm{EC}_{50}$ was calculated using nonlinear regression of a Weibull model to actual experimental data. The Weibull model is a rather flexible one, containing very few parameters, which, owing to its flexible shape, has been successfully used in many applications where an empirical model suffices (Christensen and Nyholm 1984; OECD 2006; Weibull 1951).

\section{Materials and methods}

\section{Microalgal culture}

Scenedesmus obliquus and Desmodesmus pleiomorphus unialgal cultures were isolated from a heavy metalpolluted region of Northern Portugal-"Esteiro de Estarreja". This site has for long been contaminated with heavy metals, chiefly $\mathrm{Pb}$ (approx. $835 \mathrm{mg} \mathrm{kg}^{-1}$ ), $\mathrm{Hg}$ (approx. $66 \mathrm{mg} \mathrm{kg}^{-1}$ ) and $\mathrm{Zn}$ (up to $3620 \mathrm{mg} \mathrm{kg}^{-1}$; Oliveira et al. 2001); the Cd concentration in those sediments was below detection limit.

Both species were cultured in PHM medium (Borowitzka 1988) containing $1 \mathrm{~g} \mathrm{~L}^{-1}$ of Tris-HCl buffer and trace levels of $\mathrm{Zn}\left(19.7 \mu \mathrm{g} \mathrm{L}^{-1}\right)$ in the absence of EDTA, and were maintained at $25^{\circ} \mathrm{C}$ under continuous light. Inocula for all experimental batches were obtained from exponentially growing cultures and resuspended in test medium at the desired initial cellular density. All materials and culture media were previously autoclaved for $15 \mathrm{~min}$ at $121^{\circ} \mathrm{C}$ and $1 \mathrm{~atm}$. Toxicity experiments were conducted in glass flasks, and the samples taken for cell measurements used glass tubes; all these materials were previously washed with nitric acid, and then several times with deionised water, so as to rule out any possibility for unwanted complexation of the target heavy metal cations (which would jeopardize the analytical assays).

\section{Toxicity assessment}

To determine the effect of $\mathrm{Cd}$ and $\mathrm{Zn}$ cations upon growth of both microalgae, cells were grown (in quadruplicate) in 
250-mL glass flasks on a rotary shaker set at $100 \mathrm{rpm}$ for a period of $96 \mathrm{~h}$. Aiming at the best compromise between maximizing bioassay sensitivity and having sufficient viable cells, the initial cellular density was set to $1.0-1.2$ $\times 10^{5}$ cells $\mathrm{mL}^{-1}$. Determination of cell numbers from each test flask was performed, in duplicate, using a Neubauer Improved bright-line haemocytometer. The culture medium was further supplemented with $\mathrm{Zn}$ (to levels higher than those usually considered for micronutrients) or $\mathrm{Cd}$ (herein referred to as initial metal concentrations), which were taken from stock solutions previously prepared with the corresponding chloride salts $\mathrm{ZnCl}_{2}$ and $\mathrm{CdCl}_{2}$, respectively, dissolved in deionized water. The initial $\mathrm{Zn}$ concentrations tested were $1,5,10,20,30$ and $45 \mathrm{mg} \mathrm{L}^{-1}$ for both microalgae, whereas the initial $\mathrm{Cd}$ concentrations were $0.01,0.025,0.05,0.1,0.25,0.5$ and $1 \mathrm{mg} \mathrm{L}^{-1}$ for $S$. obliquus and $0.5,1,2.5,5,10$ and $20 \mathrm{mg} \mathrm{L}^{-1}$ for $D$. pleiomorphus.

Although Cd was not listed as a major pollutant in the contaminated site from where microalgae cultures had been obtained, it is normally associated with $\mathrm{Zn}$ contamination owing to the classical nature of its industrial sources; hence, its effect upon growth of both microalgae was also assessed.

By the last day of the experiment, a sample of the culture medium was taken to determine the amount of metal left in the supernatant and thus quantify the metal removed by either microalga; that determination was according to Matsunaga et al. (1999) and Pérez-Rama et al. (2002), and resorted to atomic absorption spectrophotometry with flame atomization using a Perkin Elmer 3100 (USA) spectrophotometer.

A control experiment was also considered using culture medium (with $19.7 \mu \mathrm{g} \mathrm{L}^{-1} \mathrm{Zn}$ as trace metal requirement for micronutrient towards healthy cell grow) plus the desired microalga, and with no extra addition of either metal, in order to determine the maximum cell density reached in the cultures. A negative control, i.e. non-inoculated culture medium with the desired metal concentration, was considered as well in order to double check whether the concentration of metal in solution remained constant for the whole time frame of the experiment.

Inhibition parameter estimation

The toxicity of both metals was expressed as percent cell inhibition, calculated as:

$\%$ Cell inhibition $=\frac{(\text { biomass of control })-(\text { biomass of treatment })}{\text { biomass of control }} \times 100$.
A Weibull model was fitted to such growth inhibition data by nonlinear regression, using SPSS software v. 16.0 (USA), according to:

$\%$ Cell inhibition $=C_{\infty} \times\left[1-\exp \left(-\left[\frac{C_{\text {metal }}}{\beta}\right]^{\alpha}\right)\right]$

where $C_{\infty}$ is the maximum value of cellular inhibition and $\alpha$ and $\beta$ are the shape and concentration parameters, respectively.

The effective concentration of metal that inhibits $50 \%$ of the microalga population by $96-\mathrm{h}$ of exposure thereto (i.e. $96-\mathrm{h}_{50}$ ) was calculated afterwards by interpolation of the aforementioned model.

\section{Results}

Toxicity assessment

Exposure of either D. pleiomorphus or S. obliquus to all initial concentrations of $\mathrm{Zn}$ or $\mathrm{Cd}$, in terms of growth over a 96-h period, leads to clear differences in cell number between controls and experiments in which microalgae were exposed to toxic metals. Furthermore, growth inhibition was essentially proportional to metal concentration.

The D. pleiomorphus biomass was higher than that of the control, at the lowest $\mathrm{Zn}$ concentration considered $\left(1 \mathrm{mg} \mathrm{L}^{-1}\right)$, by 2 and 3 days of contact time; however, higher initial $\mathrm{Zn}$ concentrations reduced cell density significantly ( $p<0.05$, data not shown).

Analysis of growth of either microalga when exposed to $\mathrm{Cd}$ indicated that this metal is much more toxic than $\mathrm{Zn}$ to both species: D. pleiomorphus tolerated higher $\mathrm{Cd}$ concentrations, with its cell growth being fairly inhibited above $2.5 \mathrm{mg} \mathrm{L}^{-1}$, whereas the detrimental effect upon growth of $S$. obliquus was obvious even at as low as $0.1 \mathrm{mg} \mathrm{L}^{-1}$.

ANOVA showed that there was a significant effect of the metals tested upon growth of both microalgae. Tukey's test suggested that sorting of $\mathrm{Zn}$ initial concentrations by toxic effect was control $<1<5<10=$ $20 \leq 30<45 \mathrm{mg} \mathrm{L}^{-1}$ for $S$. obliquus and control $=1<5<$ $10=20 \leq 30=45 \mathrm{mg} \mathrm{L}^{-1}$ for D. pleiomorphus. Likewise, the toxic effects of the initial $\mathrm{Cd}$ concentrations upon growth should be sorted as: control $=0.01=0.025=0.05<$ $0.1=0.5=0.25=1 \mathrm{mg} \mathrm{L}^{-1}$ for $S$. obliquus and control $<0.5=$ $1<2.5<5<10=20 \mathrm{mg} \mathrm{L}^{-1}$ for D. pleiomorphus.

The amounts of $\mathrm{Zn}$ removal (by both microalgae) and of Cd removal (only by D. pleiomorphus) from solution during the experimental time frame are plotted in Fig. 1. 
The highest amounts of cations removed from solution, by $96 \mathrm{~h}$, were $29.2 \pm 0.6$ and $17.9 \pm 1.7 \mathrm{mg} \mathrm{L}^{-1}$ for $\mathrm{Zn}$ in the case of S. obliquus or D. pleiomorphus, respectively, at an initial concentration of $45 \mathrm{mg} \mathrm{L}^{-1}$, and $5.7 \pm 0.1 \mathrm{mg} \mathrm{L}^{-1}$ for $\mathrm{Cd}$ in the case of D. pleiomorphus at an initial concentration of $20 \mathrm{mg} \mathrm{L}^{-1}$.

\section{Inhibition parameter estimation}

Nonlinear regression of the parameters in Weibull model to cell inhibition data, pertaining to both metals and both microalgae (Table 1), led to good fits (Fig. 2), and no major trend in the residuals could be perceived. The fact that full inhibition $(100 \%)$ is never reached is a consequence of the intrinsic scatter of the data and of the unavoidable bias resulting from extrapolation to an asymptotic behaviour when not high enough metal concentrations were actually tested. However, that accuracy in modelling would be redundant because this model was used with the sole purpose of interpolating data to calculate $\mathrm{EC}_{50}$ values rather than describing asymptotic
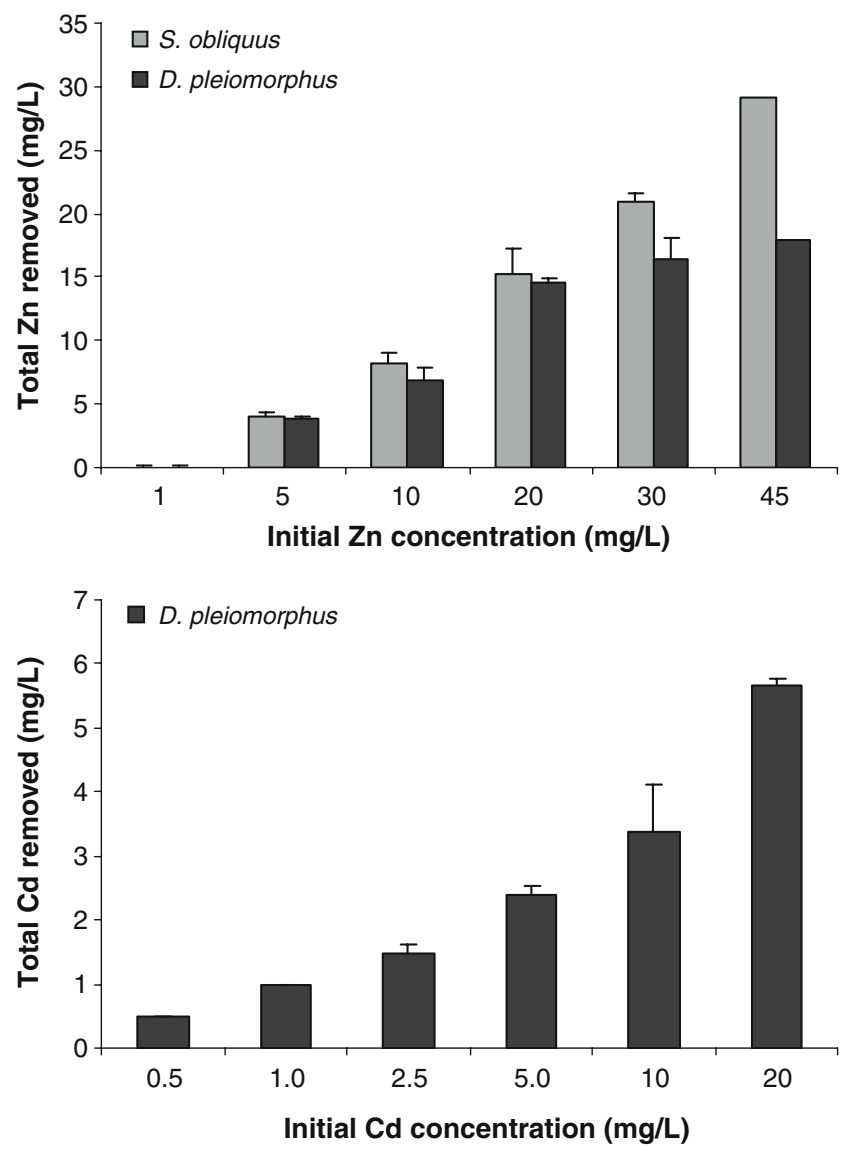

Fig. 1 Extent (average \pm standard deviation, $n=4$ ) of $\mathrm{Zn}$ and $\mathrm{Cd}$ removal by $96 \mathrm{~h}$ of exposure of the microalgae to various initial concentrations
Table 1 Best estimates (mean \pm standard deviation) of Weibull model parameters, pertaining to D. pleiomorphus and S. obliquus, by $96 \mathrm{~h}$ of exposure of the microalgae to various initial $\mathrm{Zn}$ and $\mathrm{Cd}$ concentrations

\begin{tabular}{lcccc}
\hline \multirow{2}{*}{ Microalga } & Metal & \multicolumn{3}{l}{ Weibull model parameter } \\
\cline { 3 - 5 } & & $C_{\infty}(\%)$ & $\beta(\mathrm{mg} / \mathrm{L})$ & $\alpha$ \\
\hline D. pleiomorphus & $\mathrm{Zn}$ & $74.0 \pm 1.5$ & $4.5 \pm 0.3$ & $1.5 \pm 0.2$ \\
& $\mathrm{Cd}$ & $89.5 \pm 1.6$ & $2.2 \pm 0.1$ & $1.6 \pm 0.1$ \\
S. obliquus & $\mathrm{Zn}$ & $97.1 \pm 2.0$ & $35.6 \pm 2.9$ & $0.44 \pm 0.03$ \\
& $\mathrm{Cd}$ & $91.9 \pm 1.7$ & $0.076 \pm 0.005$ & $0.92 \pm 0.07$ \\
\hline
\end{tabular}

trends of cell inhibition. Likewise, comparison with alternative models based on lack-of-fit statistical analyses was also not relevant given our purpose, so it was not pursued.

The 96-h $\mathrm{EC}_{50}$ values obtained for S. obliquus and D. pleiomorphus, after exposure to the heavy metals at stake, were 16.99 and $4.87 \mathrm{mg} \mathrm{L}^{-1}$ for $\mathrm{Zn}$ and 0.058 and $1.92 \mathrm{mg} \mathrm{L}^{-1}$ for $\mathrm{Cd}$, respectively. It can be concluded that $\mathrm{Cd}$ is highly toxic for both species, although D. pleiomorphus is less sensitive to $\mathrm{Cd}$ than $S$. obliquus. On the other hand, the $\mathrm{EC}_{50}$ values pertaining to $\mathrm{Zn}$ and $S$. obliquus suggest that this microalga tolerates significantly higher $\mathrm{Zn}$ concentrations than D. pleiomorphus.

\section{Discussion}

The capacity of a microalga to resist the toxic action of a heavy metal may be assessed via its $\mathrm{EC}_{50}$ value (Torres et al. 2000). In fact, the effective concentration of a heavy metal that causes $50 \%$ inhibition of microbial growth by $96 \mathrm{~h}$ is widely used as an index of toxicity (Yan and Pan 2002). Its calculation based on biomass instead of growth rate was elected because the latter requires data generated exclusively during the exponential phase; hence, calculation of $\mathrm{EC}_{50}$ based on biomass has fewer sources of variation associated therewith (Moreno-Garrido et al. 2000).

Recall that in order to assess the toxicity of $\mathrm{Zn}$ on the growth of microalgae, D. pleiomorphus and S. obliquus were exposed to various initial concentrations of this metal. In the former case, its biomass was higher than that of the control by 2 and 3 days of contact time at the lowest $\mathrm{Zn}$ concentration considered $\left(1 \mathrm{mg} \mathrm{L}^{-1}\right)$. This can easily be rationalized since $\mathrm{Zn}$ is a micronutrient required for microalgal metabolism (Báscik-Remisiewicz et al. 2009; Vallee and Auld 1990) as it is a part of prosthetic moieties of some of its relevant enzymes. Our strains were more tolerant to $\mathrm{Zn}$ than others described in the literature, as concluded from their higher $\mathrm{EC}_{50}$ values: 16.99 and $4.87 \mathrm{mg} \mathrm{L}^{-1}$ for $S$. 
Fig. 2 Extent of cell inhibition of D. pleiomorphus $(\mathbf{a}, \mathbf{b})$ and $S$. obliquus (c, d) by $96 \mathrm{~h}$ of exposure of the microalgae to various initial concentrations of $\mathrm{Zn}(\mathbf{a}, \mathbf{c})$ and $\mathrm{Cd}(\mathbf{b}, \mathbf{d})$ : experimental data (open symbols, average \pm standard deviation, $n=4)$ and theoretical prediction using Weibull model (solid line)
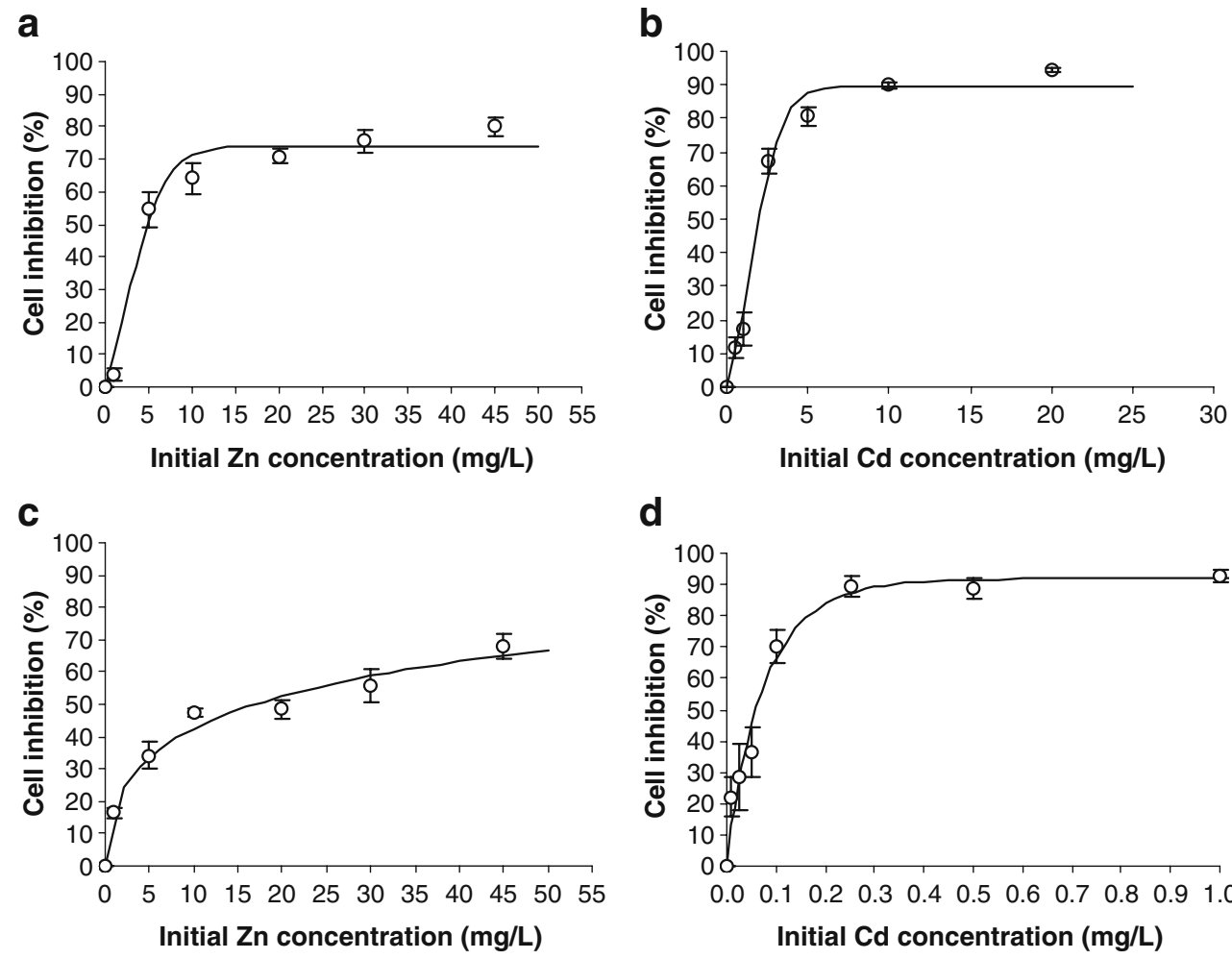

d

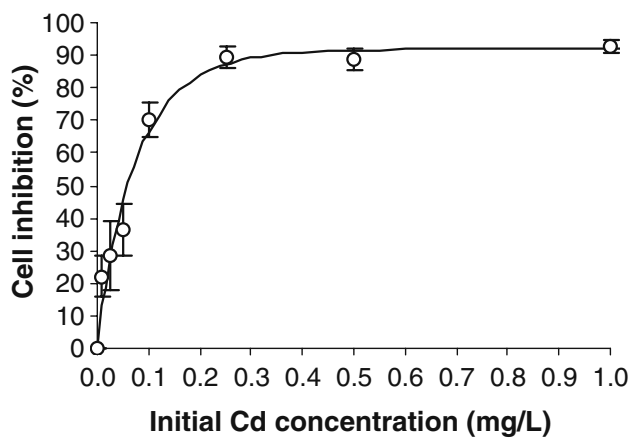

obliquus and D. pleiomorphus, respectively. Tripathi and Gaur (2006) obtained a 50\% reduction in cell number after exposure of Scenedesmus sp. to $1.64 \mathrm{mg} \mathrm{L}^{-1} \mathrm{Zn}$ by $48 \mathrm{~h}$, whereas $\mathrm{EC}_{50}$ values of 0.81 and $2.3 \mathrm{mg} \mathrm{L}^{-1}$ for $S$. quadricauda and Chlorella kessleri, respectively, were reported by Rojíčková-Padrtová and Maršálek (1999). Toumi et al. (2007) reported an $\mathrm{EC}_{50}$ of $0.34 \mathrm{mg} \mathrm{L}^{-1}$ after exposure of Micratinium pusillum to $\mathrm{Zn}$ for $72 \mathrm{~h}$. The fact that this metal was an abundant contaminant in the original source site of our microalgae strains may account (at least partially) for our outstanding observations.

Growth inhibition of microalgae in response to increasing heavy metal concentrations in the medium has been reported elsewhere (Báscik-Remisiewicz et al. 2009; Costa and França 1998; Torres et al. 2000); such toxic effects apparently depend on both microalgal species and metal concentration, besides contact time. The exposure period chosen for our study has frequently been used in similar toxicity tests and is considered to be sufficient to unfold the putative toxic effect of metals (Torres et al. 2000; Toumi et al. 2007). In particular, Omar (2002b) reported that growth of $S$. obliquus and $S$. quadricauda decreased as $\mathrm{Zn}$ concentrations increased in the culture medium; low $\mathrm{Zn}$ concentrations when growing S. obliquus (i.e. 0.5 and $1.5 \mathrm{mg} \mathrm{L}^{-1}$ ) and $S$. quadricauda (i.e. $0.5 \mathrm{mg} \mathrm{L}^{-1}$ ) permitted a gradual increase in their growth rates, whereas sudden exposure to high $\mathrm{Zn}$ concentrations of $S$. obliquus (i.e. 4.5 and $8 \mathrm{mg} \mathrm{L}^{-1}$ ) or $S$. quadricauda (i.e. $1.5,4.5$ and $8.0 \mathrm{mg} \mathrm{L}^{-1}$ ) suppressed growth, with the most notable inhibition being observed at the highest concentration, and leading to $24 \%$ and $33 \%$ growth inhibition of S. obliquus and $S$. quadricauda, respectively. Nalimova et al. (2005) also described growth inhibition of Spirulina platensis cultures following exposure to higher and higher $\mathrm{Zn}$ concentrations.

Comparing the amount of $\mathrm{Zn}$ taken out from solution by both microalgae, by the last day of exposure, S. obliquus revealed a higher capacity to remove $\mathrm{Zn}$ than $D$. pleiomorphus at all initial concentrations experimented with (Fig. 1). The highest level of metal removal $\left(29.2 \mathrm{mg} \mathrm{L}^{-1}\right)$ was attained at the highest initial metal concentration $\left(45 \mathrm{mg} \mathrm{L}^{-1}\right)$.

Concerning exposure of both microalgae to $\mathrm{Cd}$, growth inhibition was noticed right from the lowest metal concentration tested, with strong inhibition following exposure to the highest levels. Likewise, $S$. obliquus was more sensitive to $\mathrm{Cd}$ than D. pleiomorphus one. Toxicity studies reported by a few authors have revealed higher $\mathrm{EC}_{50}$ values for $\mathrm{Cd}$ than those obtained in our study $\left(0.058\right.$ and $1.92 \mathrm{mg} \mathrm{L}^{-1}$ for $S$. obliquus and D. pleiomorphus, respectively), showing that our strains are more sensitive to this toxic metal. For instance, an $\mathrm{EC}_{50}$ of $22.39 \mathrm{mg} \mathrm{L}^{-1}$ for $\mathrm{Cd}$ was reported by Torres et al. (2000) in the case of P. tricornutum after exposure for $96 \mathrm{~h}$; Báscik-Remisiewicz et al. (2009) found an $\mathrm{EC}_{50}$ of $16.8 \mathrm{mg} \mathrm{L}^{-1}$ for $\mathrm{CdCl}_{2}$ in the case of Desmodesmus armatus by 24 h; Tukaj et al. (2007) obtained an $\mathrm{EC}_{50}$ of $10.45 \mathrm{mg} \mathrm{L}{ }^{-1}$ for $\mathrm{CdCl}_{2}$ in the case of Scenedesmus armatus by $24 \mathrm{~h}$; and Lam et al. (1999) claimed an $\mathrm{EC}_{50}$ of $2.48 \mathrm{mg} \mathrm{L}{ }^{-1}$ for $\mathrm{Cd}$ in the case 
of Chlorella vulgaris. On the other hand, Visviki and Rachlin (1994) described an $\mathrm{EC}_{50}$ value much more similar to that obtained here: $0.5 \mathrm{mg} \mathrm{L}^{-1}$ of Cd for Dunaliella salina by 96 h. Finally, Toumi et al. (2007) exposed cells of $M$. pusillum to different levels of $\mathrm{Cd}$ and reported an $\mathrm{EC}_{50}$ value of $0.28 \mathrm{mg} \mathrm{L}^{-1}$ by $72 \mathrm{~h}$.

Cain et al. (1980) found that growth of S. obliquus was markedly affected by concentrations of $\mathrm{Cd}$ above $1 \mathrm{mg} \mathrm{L}^{-1}$ and that the extent of inhibition correlated directly with that concentration. Visviki and Rachlin (1991) attributed the reduction of microalgal growth, as driven by toxic metals, to the inhibition of normal cell division because of metal binding to sulfhydryl groups that are important in regulating such a metabolic process. Costa and França (2003) reported that $\mathrm{Cd}$ in soluble form markedly affected cell growth of Tetraselmis chuii, with a $60 \%$ inhibition when exposed to $10.0 \mathrm{mg} \mathrm{L}^{-1}$. Yan and Pan (2002) also reported a decrease in the growth of $S$. obliquus following exposure to increasing initial concentrations of the (related transition) metal $\mathrm{Cu}$, whereas Mohammed and Markert (2006) found that the growth rate of $S$. quadricauda decreased upon addition of $\mathrm{Cd}$; these authors claimed that this inhibition should be attributed to toxic effects exerted mainly on the respiratory process.

Comparing the amount of metal taken out from solution at similar initial metal concentrations (e.g. $20 \mathrm{mg} \mathrm{L}^{-1}$ ), $\mathrm{Zn}$ was removed to a larger extent. A plausible explanation for this is that small amounts of $\mathrm{Zn}$ could be used by the cell as actual micronutrients (e.g. for enzyme synthesis) besides the amount of metal adsorbed onto the cell surface, whereas $\mathrm{Cd}$ is not necessary for cell metabolism at all, so it is solely (or mainly) removed by adsorption. The higher toxicity, to both species, of $\mathrm{Cd}$ than $\mathrm{Zn}$ may thus derive from the former being a nonessential element for living organisms, with no known biological function (Tukaj et al. 2007). Therefore, the reduction observed in the growth of microalgal cells, when in the presence of increasing concentrations of $\mathrm{Zn}$ and $\mathrm{Cd}$, does apparently result from interference with basic physiological processes (e.g. cell division, membrane assembling, photosynthesis and respiration) owing to their great affinity for biological structures that contain -SH groups; occurrence of severe toxic effects at high concentrations would then cause cell enlargement and structural damages (e.g. thylakoid disorganization in the chloroplasts) that will eventually cause cell death (Nalimova et al. 2005; la Rocca et al. 2009). As a selfdefence mechanism against the toxic effects of said metal ions, microalgal cells are equipped with machinery for extracellular adsorption or intracellular complexation, the efficiency of which is reflected on their $\mathrm{EC}_{50}$ value for each specific metal ion (Nacorda et al. 2007).

Microalgae are some of the most important organisms in our ecosystem because they are the main producers lying on the base of the food chain. Microalgae are characterized by rapid growth rates and ubiquitous distribution throughout natural environments, yet they show a critical sensitivity to environmental variations (e. g. nutrient levels and presence of pollutants); this is why the use of microalgae as test organisms is gaining importance. Furthermore, microalgal toxicity tests are quick and inexpensive, and can be effectively used to assess those toxic substances that are found in concentrations too low for conclusive detection via higher trophic organisms (Wong and Couture 1986). Finally, there is a likely application of microalgae in determining toxicity of metal ions in situ because the microalgal species used already exist in a contaminated environment, so any change in the levels of the toxic metals will be directly reflected upon the size of its population.

\section{Conclusions}

The 96- $\mathrm{ECC}_{50}$ values obtained were 0.058 and $1.92 \mathrm{mg} \mathrm{L}^{-1}$ for $\mathrm{Cd}$ and 16.99 and $4.87 \mathrm{mg} \mathrm{L}^{-1}$ for $\mathrm{Zn}$, in the case of $S$. obliquus and D. pleiomorphus, respectively. Cd was toxic to $S$. obliquus and D. pleiomorphus at much lower concentrations than happened with $\mathrm{Zn}$. $\mathrm{Cd}$ and $\mathrm{Zn}$ significantly inhibited growth of both microalga species at the highest concentrations tested, whereas lower concentrations caused only a slow decline in microalgal biomass; at the lowest $\mathrm{Zn}$ concentration considered (i.e. $1 \mathrm{mg} \mathrm{L}^{-1}$ ), an increase in the growth of $D$. pleiomorphus cells was actually observed. The Weibull model provided a good fit to data pertaining to the inhibition of both microalgae upon exposure to either $\mathrm{Zn}$ or $\mathrm{Cd}$ ions, so it may be useful in attempts to calculate $\mathrm{EC}_{50}$ values associated with toxic effects in aquatic ecosystems at large. In view of the increasing contamination of aquatic ecosystems by toxic metals, and given the placement of microalgae at the basis of the food chain, ecotoxicological studies (as the one reported here) encompassing wild strains are of greatest importance towards the design of bioremediation strategies and integrated environmental monitoring.

Acknowledgements The authors are grateful to Câmara Municipal de Estarreja for allowing full access to the contaminated site. This work was supported by Fundação para a Ciência e Tecnologia and Fundo Social Europeu (III Quadro Comunitário de Apoio), via a PhD research fellowship granted to author C. M. Monteiro (ref. SFRH/BD/ 9332/2002) and supervised by author F. X. Malcata.

\section{References}

Allen HE, Hall RH, Brisbin TD (1980) Metal speciation. Effects on aquatic toxicology. Environ Sci Technol 14:441-443 
Báscik-Remisiewicz A, Tomaszewska E, Labuda K, Tukaj Z (2009) The effect of $\mathrm{Zn}$ and $\mathrm{Mn}$ on the toxicity of $\mathrm{Cd}$ to the green microalga Desmodesmus armatus cultured at ambient and elevated $(2 \%) \mathrm{CO}_{2}$ concentrations. Polish J Environ Stud 18:775-780

Blaise C, Ménard L (1998) A microalgal solid-phase test to assess the toxic potential of freshwater sediments. Water Qual Res 33:133-151

Borowitzka MA (1988) Algal media and sources of algal cultures. In: Borowitzka MA, Borowitzka LJ (eds) Microalgal Biotechnology. Cambridge University Press, Cambridge, pp 456-466

Cain JR, Paschal DC, Hayden CM (1980) Toxicity and bioaccumulation of cadmium in the colonial green alga Scenedesmus obliquus. Arch Environm Contam Toxicol 9:9-16

Christensen ER, Nyholm N (1984) Ecotoxicological assays with algae: Weibull dose-response curves. Environ Sci Technol 18:713-718

Costa ACA, França FP (1998) The behaviour of the microalgae Tetraselmis chuii in cadmium-contaminated solutions. Aquac Int 6:57-66

Costa ACA, França FP (2003) Cadmium interaction with microalgal cells, cyanobacterial cells, and seaweeds: toxicology and biotechnological potential for wastewater treatment. Mar Biotechnol 5:149-156

Franklin NM, Stauber JL, Apte SC, Lim RP (2002) Effect of initial cell density on the bioavailability and toxicity of copper in microalgal bioassays. Environ Toxicol Chem 21:742-751

Herpin U, Berlekamp J, Markert B, Wolterbeek B, Grodzinska K, Siewers U, Lieth H, Weckert V (1996) The distribution of heavy metals in a transect of the three states The Netherlands, Germany and Poland, determined with the aid of moss monitoring. Sci Total Environ 187:185-198

Knauer K, Behra R, Sigg L (1997) Effects of free $\mathrm{Cu}^{2+}$ and $\mathrm{Zn}^{2+}$ ions on growth and metal accumulation in freshwater algae. Environ Toxicol Chem 16:220-229

Lam PKS, Wut PF, Chan ACW, Wu RSS (1999) Individual and combined effects of cadmium and copper on the growth response of Chlorella vulgaris. Environ Toxicol 14:347-353

Matsunaga T, Takeyama H, Nakao T, Yamazawa A (1999) Screening of marine microalgae for bioremediation of cadmium-polluted seawater. J Biotechnol 70:33-38

Mbabazi J, Twinomuhwezi $\mathrm{H}$, Wasswa J, Ntale M, Mulongo G, Kwetegyeka J, Schrøder KH (2010) Speciation of heavy metals in water from the Uganda side of Lake Victoria. Inter J Environ Stud 67:9-15

Mohammed MH, Markert B (2006) Toxicity of heavy metals on Scenedesmus quadricauda (Turp.) de Brébisson in batch cultures. Environ Sci Pollut Res 13:98-104

Moreno-Garrido I, Lubián LM, Soares AMVM (2000) Influence of cellular density on determination of $\mathrm{EC}_{50}$ in microalgal growth inhibition tests. Ecotoxicol Environ Saf 47:112-116

Nacorda JO, Martinez-Goss MR, Torreta NK, Merca FE (2007) Metal resistance and removal by two strains of the green alga Chlorella vulgaris Beijerinck, isolated from Laguna de Bay, Philippines. J Appl Phycol 19:701-710

Nalimova AA, Popova VV, Tsoglin LN, Pronina NA (2005) The effects of copper and zinc on Spirulina platensis growth and heavy metal accumulation in its cells. Russian J Plant Physiol $52: 229-234$
Oliveira RS, Dodd JC, Castro PML (2001) The mycorrhizal status of Phragmites australis in several polluted soils and sediments of an industrialised region of Northern Portugal. Mycorrhiza 10:241247

Omar HH (2002a) Adsorption of zinc ions by Scenedesmus obliquus and $S$. quadricauda and its effect on growth and metabolism. Biologia Plant 45:261-266

Omar HH (2002b) Bioremoval of zinc ions by Scenedesmus obliquus and Scenedesmus quadricauda and its effect on growth and metabolism. Int Biodeterior Biodegrad 50:95-100

Organization for the Economic Cooperation and Development (2006) Freshwater alga and cyanobacteria, growth inhibition test. OECD Guidelines for the Testing of Chemicals, Guideline 201, Paris, France, pp 1-13

Pérez-Rama M, Alonso JA, López CH, Vaamonde ET (2002) Cadmium removal by living cells of the marine microalga Tetraselmis suecica. Bioresour Technol 84:265-270

la Rocca N, Andreoli C, Giacometti GM, Rascio N, Moro I (2009) Responses of the Antarctic microalga Koliella antarctica (Trebouxiophyceae, Chlorophyta) to cadmium concentration. Photosynthetica 47:471-479

Rojičková-Padrtová R, Maršálek B (1999) Selection and sensitivity comparisons of algal species for toxicity testing. Chemosphere 38:3329-3338

Sanitá di Toppi L, Gabbrielli R (1999) Response to cadmium in higher plants. Environ Exp Bot 41:105-130

Torres E, Cid A, Herrero C, Abalde J (2000) Effect of cadmium on growth, ATP content, carbon fixation and ultrastructure in the marine diatom Phaeodactylum tricornutum Bohlin. Water Air Soil Pollut 117:1-14

Toumi A, Belkoura M, Benabdallah S, el Alami M, Idrissi L, Nejmeddine A (2007) Effet et bioaccumulation des métaux lourds ( $\mathrm{Zn}, \mathrm{Cd})$ chez l'algue Micractinium pusillum. Environ Technol 28:19-23

Tripathi BN, Gaur JP (2006) Physiological behaviour of Scenedesmus sp. during exposure to elevated levels of $\mathrm{Cu}$ and $\mathrm{Zn}$ and after withdrawal of metal stress. Protoplasma 229:1-9

Tukaj Z, Báscik-Remisiewicz A, Skowroński T, Tukaj C (2007) Cadmium effect on the growth, photosynthesis, ultrastructure and phytochelatin content of green microalga Scenedesmus armatus: a study at low and elevated $\mathrm{CO}_{2}$ concentration. Environ Exper Bot 60:291-299

Vallee BL, Auld DS (1990) Zinc coordination, function and structure of zinc enzymes and other proteins. Biochemistry 29:5647-5659

Visviki L, Rachlin JW (1991) Ultrastructural changes in Dunaliella minuta following acute and chronic exposure to copper and cadmium. Arch Environ Contam Toxicol 23:420-425

Visviki I, Rachlin D (1994) Acute and chronic effect exposure of Dunaliella salina and Chlamydomonas bullosa to copper and cadmium: effects on ultrastructure. Arch Environ Contam Toxicol 26:154-162

Weibull W (1951) A statistical distribution function of wide applicability. J Appl Mech 18:293-297

Wong PTS, Couture P (1986) Toxicity screening using phytoplankton. In: Dutka BJ, Bitton G (eds) Toxicity Testing using Microorganisms. CRC, Boca Raton, pp 79-100

Yan H, Pan G (2002) Toxicity and bioaccumulation of copper in three green microalgal species. Chemosphere 49:471-476 